\title{
A Novel Concept for Sustainable Food Production Utilizing Low Temperature Industrial Surplus Heat
}

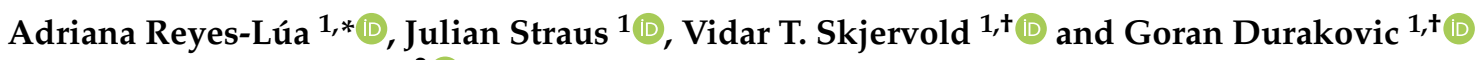 \\ and Tom Ståle Nordtvedt ${ }^{2}$ (D) \\ 1 SINTEF Energy Research, Kolbjørn Hejes vei 1B, 7491 Trondheim, Norway; julian.straus@sintef.no (J.S.); \\ vidar.t.skjervold@ntnu.no (V.T.S.); goran.durakovic@ntnu.no (G.D.) \\ 2 SINTEF Ocean, Mailbox 4762 Torgarden, 7465 Trondheim, Norway; tom.s.nordtvedt@sintef.no \\ * Correspondence: adriana.r.lua@sintef.no
}

Citation: Reyes-Lúa, A.; Straus, J.; Skjervold, V.T.; Durakovic, G.;

Nordtvedt, T.S. A Novel Concept for Sustainable Food Production Utilizing Low Temperature Industrial Surplus Heat. Sustainability 2021, 13, 9786. https://doi.org/10.3390/ su13179786

Academic Editor: Olivier Vitrac

Received: 28 June 2021

Accepted: 26 August 2021

Published: 31 August 2021

Publisher's Note: MDPI stays neutral with regard to jurisdictional claims in published maps and institutional affiliations.

Copyright: (c) 2021 by the authors. Licensee MDPI, Basel, Switzerland. This article is an open access article distributed under the terms and conditions of the Creative Commons Attribution (CC BY) license (https:// creativecommons.org/licenses/by/ $4.0 /)$.

\begin{abstract}
Low temperature industrial surplus heat represents a major energy source that is currently only rarely utilized due to its low quality. An agricluster allows for the leveraging of this low-quality heat and, hence, may improve the overall energy efficiency. This paper presents the novel concept of an agricluster driven by available surplus heat from industrial processes. We propose the integration of greenhouse production, insect rearing, fish rearing, and drying of seaweed using low temperature surplus heat from the aluminum industry. Each of these processes is already used in or investigated for utilization of surplus heat and partly coupled with other processes, such as in aquaponics. However, the integration of all processes in an agricluster-as proposed in this paper-may result in improved utilization of the surplus heat due to the different seasonality of the heat demand. The potential synergies of this integration approach are discussed in this paper. Furthermore, waste from one process can be utilized as an input stream to other processes, reducing the demand for external material input to the system. The proposed concept of an agricluster is especially interesting for the Nordic countries, as they are dependant on fresh food imports due to the low outside temperatures.
\end{abstract}

Keywords: surplus heat utilization; improved energy efficiency; agricluster; low temperature heat; surplus heat

\section{Introduction}

In recent years, the transition to a sustainable society has been formalized through the introduction of new policies and roadmaps. The predominant example is the European Green Deal, which aims to make the European Union's economy sustainable by turning climate and environmental challenges into opportunities [1]. This includes, among others, providing cleaner energy and a globally competitive and resilient industry in addition to improving the well-being of citizens with healthy and affordable food. This roadmap is in line with previous actions within the European Union, such as the Directive (EU) 2018/2002 of the European Parliament and of the Council [2], which limits the primary energy demand to 1273 Mtoe (53,298 PJ) and the final energy demand to 956 Mtoe (40,026 PJ) in 2030 (EU28, adjusted after the United Kingdom of Great Britain and Northern Ireland left the European Union in 2020). As a reference, the final energy consumption of the EU28 corresponded to 1062 Mtoe (44,463 PJ) in 2018. The circular economy action plan adopted by the European Commission in 2020 [3] is one of the main building blocks of the European Green Deal. This action plan identifies food, water, and nutrients as being among the main key product value chains in the promotion of circularity [4]. Sustainable and local food production systems are also a response to the Farm to Fork strategy, which is also at the core of the European Green Deal and aims to make food systems fair, healthy, and environmentally friendly [5]. Thus, within Europe, the European Commission is a key player promoting the development of sustainable agri-food companies. The European Agricultural Fund for Rural Development (EAFRD) is the funding instrument of the 
Common Agricultural Policy that supports rural development strategies and projects, and an important part of the budget is spent through the implementation of rural development programs [4].

The introduction of roadmaps for a sustainable economy as well as energy efficiency regulations on national and international levels, such as the ones mentioned above, leads to the requirement of reducing both primary and final energy demand. Within the industrial sector, it is challenging to reduce the energy consumption while satisfying a potentially increasing production demand as a large share of the required energy is lost to the surroundings as heat. Process improvements may reduce inefficiencies and heat loss and, hence, alleviate this problem. However, there are technological and economical limitations for the implementation of process improvements [6]. Moreover, once practical process improvements have been implemented, available surplus heat may not have any internal use and is thus released to the surroundings. It is therefore evident that alternative means of utilizing surplus heat should be investigated to minimize heat release to the surroundings and reduce the overall energy demand while satisfying market needs. Direct heat utilization in industrial processes requiring low temperature heating, such as food production, represents an attractive alternative for reducing overall energy demand.

In general, increased energy inputs into food production are reflected as yield improvements. However, particularly when energy-intensive steps such as drying and processing are required, it can be the case that significantly more energy is used than the energy contained in the final product [7], opening opportunities for surplus heat utilization and the development of more energy-efficient production schemes. The reduction of energy demand can be boosted with material recycling, which has a significant impact on energy consumption and greenhouse gas (GHG) emissions [8]. The importance of integration of components of agricultural systems to reduce energy-based inputs is well-acknowledged, e.g., [9]. In addition, the integration of different components in a circular food production system allows for the utilization of by-products, nutrient recycling, and waste minimization [10]. This can be achieved by considering circular economy concepts in agri-food production, which imply the utilization of minimal amounts of external inputs, closing the nutrient loops, valorizing agri-food waste, and reducing negative discharges, such as waste and emissions in the environment [4].

To our best knowledge, there are no investigations of the integration of food production processes for exploiting synergies between the individual processes as well as surplus heat from industry. Hence, this paper proposes the concept of an agricluster enabled through the availability of low temperature industrial surplus heat. Within the agricluster, the individual processes are coupled to improve both surplus heat utilization as well as waste management and supply chains of the individual processes. The proposed agricluster exploits the synergies of individual processes for the efficient utilization of industrial surplus heat for sustainable food production.

This paper is structured as follows. Section 2 provides an outlook on the availability of surplus heat in industry and alternative methods for its utilization, with a focus on food production. Section 3 describes the main components of the proposed agricluster, namely greenhouses (Section 3.1), fish production (Section 3.2), insect production (Section 3.4), and seaweed drying (Section 3.3). While presenting the reasoning for selecting these components and describing opportunities for surplus heat utilization, we also mention the impact of heat requirements on these industries. In Section 4, the material flow integration between the different described processes is examined as a means to improve both the utilization of the surplus heat and the resulting waste streams from the individual processes. Section 5 proposes a novel agricluster integrating all discussed processes and discusses the implications of this integration. Section 6 highlights the main conclusions of this paper.

\section{Surplus Heat in Industry}

In this section, we review the available studies regarding the availability of low temperature surplus heat, with focus on the Nordic countries and aluminum production, which is a significant source of surplus heat. We also present potential alternatives for its utilization, with focus on the direct use of surplus heat for food production. 


\subsection{Low Temperature Surplus Heat Availability in Industry}

Most surplus energy within a system is in the form of heat and, in general, the greatest amount is available at lower temperatures and at a plant level [11]. The surplus heat potential may vary among regions depending on factors such as the industrial structure. Information regarding the temperature ranges of the available surplus heat also varies among studies. This is because the minimum temperature for viable heat recovery varies among processes. Moreover, it is challenging to obtain exact, often confidential, data on surplus heat. Therefore, most investigations are based on extrapolations from other available data such as industrial $\mathrm{CO}_{2}$ emissions [12]. There is, however, a clear trend toward a high share of surplus heat within the low temperature range. As an example for the quantification of surplus heat in industry, Forman et al. [13] conducted a study to estimate the global waste heat potential and found that approximately $42 \%$ of surplus heat in the industrial sector is available at temperatures below $100{ }^{\circ} \mathrm{C}$ and $20 \%$ at temperatures within the range of $100-299^{\circ} \mathrm{C}$. Johnson et al. [14] found out that $60 \%$ of industrial waste heat in the United States corresponded to streams below $60^{\circ} \mathrm{C}$.

In the Nordic countries, a study conducted by ENOVA in 2009 [15] assessed the total surplus heat from the Norwegian industry. The respondents of the study represented $63 \%$ of the Norwegian industrial energy consumption, with a large share of the metallurgic sector. The surplus heat accounted for $36 \%$ of the energy consumption of $53.7 \mathrm{TWh} / \mathrm{a}$, with a major share being emitted either in cooling water or flue gas. The same study found that $47 \%$ of surplus heat in Norway corresponds to temperatures below $60^{\circ} \mathrm{C}$. According to this study, the metallurgic sector, e.g., the aluminum and ferroalloy industries, emits a large share of the surplus heat of the industrial production in Norway and is therefore a significant source of low temperature surplus heat [15]. To the best knowledge of the authors, there is no study in other Nordic countries accounting for surplus heat within specific temperature ranges, but similar results should be expected in other countries with important metallurgic activity (e.g., the steel industry in Sweden [16]). The aforementioned studies highlight the scale of low temperature heat losses in industry and the importance of identifying utilization alternatives for surplus heat.

Aluminum production corresponds to a large part of the Norwegian metal industry [17], and Norway is the largest producer of primary aluminum in Europe [18]. The aluminum industry is one of the most energy-intensive industries in the world, standing for around $3.5 \%$ of global electricity consumption [19] and nearly $2 \%$ of the world's total $\mathrm{CO}_{2}$ emissions [20]. Around half of the energy input to an aluminum production plant is lost to the surroundings as surplus heat.

The ENOVA study mentioned above [15] assigned the surplus heat from the Norwegian aluminum industry to different temperature levels. The results from this study are summarized in Figure 1.

The total amount of surplus heat is $2225 \mathrm{GWh} / \mathrm{a}$ and is mostly available either between 25 and $40^{\circ} \mathrm{C}$ or 60 and $140{ }^{\circ} \mathrm{C}$. A similar study performed energy mapping of the Alcoa Deschambault Quebec smelter in Canada, showing that the potline off-gas and pot surfaces clearly were the largest sources of surplus heat, approximately an order of magnitude larger than other heat sources [21].

Several different concepts for heat recovery from aluminum smelter off-gas have been investigated, e.g., bundles of oval tubes with rectangular fins [22,23], rows of cooled, vertical, and retractable plates [24], and off-gas flow on the inside of straight tubes [25-27]. However, due to the low quality of the rejected heat and a lack of nearby heat demands, there is limited re-utilization of heat in this industry [21]. For this reason, we use this industry as an example of a potential source of surplus heat for the agricluster proposed in this paper. 


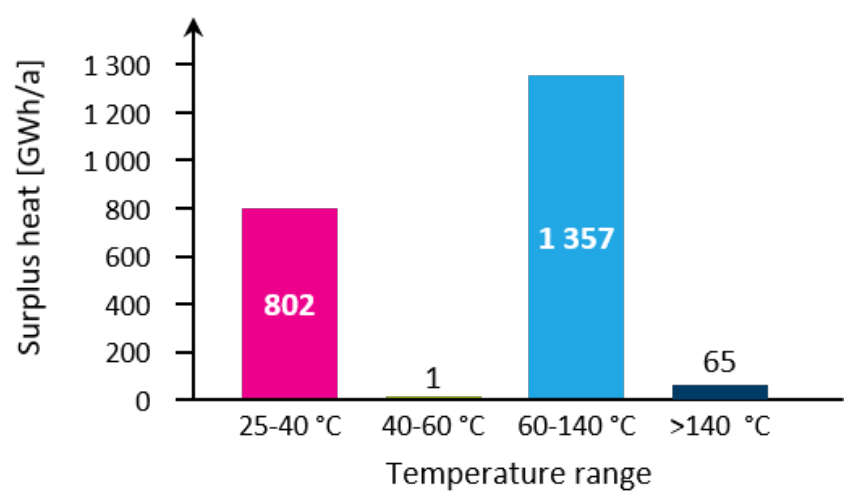

Figure 1. Amount of surplus heat in the Norwegian aluminum industry sorted according to temperature level. Based on data from ENOVA [15].

\subsection{Alternatives for Industrial Surplus Heat Utilization}

Industrial surplus heat utilization has received considerable attention due to its large potential and its importance for reducing energy consumption.

Some surplus heat utilization methods have been investigated, e.g., heat-to-power conversion via Stirling engines [28] and organic Rankine cycles [12,29]. However, Law et al. [30] showed that it is more economical to recover heat for transfer to a sink than to invest in heat pumps or convert the heat into other forms such as electricity. Oluleye et al. [31,32] compared different "waste heat utilization technologies", applying an economic ranking and a reduction in $\mathrm{CO}_{2}$ emissions. They also developed a framework to assess different technologies based on exergy degradation and concluded that using surplus heat directly for heating purposes is desirable due to higher efficiency and lower exergy loss. In this study, direct heat recovery in, e.g., the form of space heating proved beneficial over a wide range of surplus heat temperatures if the sink was close in temperature to the heat source. Similarly, Kavvadias and Quoilin [33] developed a model that compares, on an economic basis, district heating with gas heaters and heat pumps, highlighting the importance of considering the transport distance from the surplus heat source to the district heating demand.

Space heating and district heating represent the highest potential for direct utilization of industrial surplus heat [34]. This includes, for example, surplus heat from research facilities [35]. However, the profitability of district heating systems depends on population density [12], and Nordic countries tend to have low population densities away from the main cities. Moreover, available surplus heat exceeds district heating demands in Sweden [36]. Similarly, there is in general a lack of district heating demand close to large industrial sites in Norway. This includes, e.g., the Hydro aluminum plants on Karmøy ( 43,000 inhabitants [37]) and in Sunndalsøra (<7000 inhabitants [38]) and Alcoa's aluminum plant in Mosjøen ( $<13,000$ inhabitants [38]). Hence, district heating does not represent a sufficient demand in these locations. Another aspect to consider is that these plants are located in regions with limited space for large new installations due to the local geography. Moreover, the population in these regions is not likely to grow such that the future district heating demand meets available surplus heat. Hence, alternative processes are required that may utilize low temperature heat.

Lauterbach et al. [39] mapped the industrial heat demand for Germany in different temperature ranges for utilizing solar heat in industry. This mapping shows that the food and beverage sector represents a significant demand in the range below $100{ }^{\circ} \mathrm{C}$. As low temperature processes dominate the energy usage for food and drink processing, this industry is an attractive alternative for low-grade heat recovery [30]. Food production is already an important sector for utilization of industrial surplus heat [30,40], and efficiency improvements in the provision and management of process heat have been discussed to reduce emissions [41]. Furthermore, the unaccounted growing of crops and aquaculture may represent a significant demand for heat. Hence, food production may be an environ- 
mentally and economically profitable alternative to district heating for the utilization of low temperature surplus heat.

There already exist several applications highlighting the potential of utilizing surplus heat for food production in Nordic conditions. Currently, surplus heat is utilized at, e.g.,:

1. Miljøgartneriet greenhouse in Nærbø (Southern Norway), which uses surplus $\mathrm{CO}_{2}$ and warm wastewater from a nearby dairy plant [42],

2. The Elleholms Tomatodling greenhouse producing tomatoes in Mörrum (Southern Sweden), which uses excess heat from Södra Cell, a nearby pulp mill [43,44].

3. Mo Industri Park in Mo i Rana (Northern Norway), where surplus heat in the cooling water from the industrial cluster is used in smolt production $[45,46]$.

4. Tjeldbergodden Bioparken (Central Norway), in which the surplus heat in the cooling water from a methanol plant is used in post-smolt and lumpfish farming [47].

5. Eramet Kvinesdal (Southern Norway) for the production of turbot utilizing surplus heat from the production of silicomanganese by Stolt Sea Farm [48].

6. Reykjanes Resource Park (Southwest Iceland) for the production of Senegalese sole with surplus heat from the cooling water of a geothermal power plant by Stolt Sea Farm [49].

In these examples, surplus heat is used for greenhouse vegetable production and onshore fish production, which are considered in this paper. In addition, we also describe requirements for insect rearing and seaweed drying.

\section{Identification of Agricluster Components and Surplus Heat Utilization Possibilities}

As described in Section 2.2, industrial surplus heat is already utilized in greenhouse and fish production in the Nordic countries. In this section, we expand the requirements for these utilization alternatives. We also introduce two novel potential utilization alternatives, namely seaweed drying and insect rearing. The interest in seaweed production is rapidly growing in countries with long coastlines such as Norway [50]. Drying is a critical step in the value chain of seaweed products and requires high quantities of heat due to the high water content of seaweed. Insects and insect-based ingredients are starting to draw attention as sustainable and ethical alternatives to traditional protein sources [51], and similarly to greenhouses and fish production, low temperature heat is required to maintain an adequate growth temperature.

\subsection{Greenhouse Production}

Large-scale efficient agricultural production requires appropriate nutrients, temperature, humidity, and light conditions. Annual yield (production/area) depends on factors such as plantings per year, plant density, irrigation system and patterns, ventilation, greenhouse structure, $\mathrm{CO}_{2}$ enrichment, soil, and ambience (temperature, light, humidity) control [52-54]. The optimal greenhouse temperature will depend on the specific crop, but it will usually be in the range of $10-35^{\circ} \mathrm{C}$. A large share of production costs of greenhouses are related to energy consumption [55,56], which is used for inside air heating to accelerate crop growth and development and for controlling air humidity [57].

In the Nordic region, non-native crops need to be grown in greenhouses, which allows for providing the required conditions for growth. Tomatoes represent a large share of the production of greenhouse vegetables in the Nordic region [58-60], but large amounts are still being imported. In the case of Norway, only one-third of the consumed tomatoes are produced locally, and annual imports are in the range of $24 \mathrm{kt} / \mathrm{a}$ [61-63]. Hence, there is a sufficient market for increasing local production if costs become competitive. Moreover, high yields can be achieved with greenhouse tomato, which is convenient in areas with limited space for new installations. Despite not being among the largest tomato producers, the Nordic countries are in the top ten countries regarding yield [52]. Thus, although other crops are grown in greenhouses in the Nordic region $[60,64]$, this study considers greenhouse tomato production.

In Northern Europe, tomato is mostly produced in high-tech framed glass greenhouses with raised-bed systems. In Southern Europe, only production for the fresh market is grown 
in greenhouses [65-68]. Optimum mean daily temperature for growth is $20-25^{\circ} \mathrm{C}$, with night temperatures between 10 and $20^{\circ} \mathrm{C}$. Relatively dry conditions are preferred, and relative air humidity needs to be kept lower than $75 \%$ to maintain yield and reduce incidence of pests and fruit rotting [52]. The growing period for tomatoes is $90-150$ days, meaning that there can be up to three plantings per year, which may be done in production-intensive greenhouses. Some of the high-tech greenhouses in Northern Europe are hydroponic. "Hydroponic" can refer to soilless culture or to systems in which no solid substrate is used and water flows almost constantly down troughs holding plant roots [68]. Rockwool has a high air-holding capacity, good capillarity, and is the most common substrate for soilless tomato, but other substrates such as vermiculite, perlite, peat, and pumice may also be used $[57,68,69]$. It should be noted that in Europe, hydroponics are not allowed under organic schemes [67].

Greenhouse tomatoes have a higher carbon footprint than open-field tomatoes. Pérez Neira et al. [70] estimated that Spanish tomatoes produced in heated greenhouses had a 2.75 times higher carbon footprint and 3.3 higher cumulative energy demand than unheated crops. The main contribution to greenhouse gas (GHG) emissions comes from energy use for heating greenhouses [71,72]. Theurl et al. [73] studied tomatoes consumed in Austria and contrasted GHG emissions of those produced locally with those produced in Spain or Italy. They concluded that greenhouse gas emissions from tomato production are highly dependent on the production system, such as the prevalence or absence of heating. Referring to the Nordic region, Verheul and Thorsen [74] analyzed emissions of six Norwegian greenhouses using natural gas as a heat source and the farm gate as the system boundary. They estimated that approximately $93 \%$ of $\mathrm{CO}_{2}$ emissions from production of tomatoes in Norway come from heating. Karlsson [75] performed an study comparing the environmental impact of producing tomatoes in Swedish greenhouses with importing tomatoes from the Netherlands or Spain. They concluded that greenhouse climate control and the transportation of produce are the most important contributors to the environmental impact. Specifically, the study concluded that in a Northern European context, the energy source for climate control of greenhouses is more significant than transportation distances. Stoessel et al. [76] arrived to similar conclusions when analyzing production in Swiss greenhouses. It should be noted that when looking at carbon footprint, the reported values are highly dependent on the methodology used, available information, and system boundaries [71,77]. With this in mind, the impact of the energy source can be observed when comparing the GHG emissions of Dutch tomatoes, which produce $1.7-2.8 \mathrm{~kg} \mathrm{CO} 2 \mathrm{eq} / \mathrm{kg}$ when using natural gas and $1.1 \mathrm{~kg} \mathrm{CO} 2 \mathrm{eq} / \mathrm{kg}$ when using combined heat and power (CHP) with increased energy efficiency [71,78]. Therefore, the utilization of otherwise wasted low temperature heat has the potential for further reducing GHG emissions and improving energy efficiency in greenhouse production.

Heating requirements, and the associated GHG emissions, are clearly dependent on ambient conditions, which show considerable variations throughout the year in the Nordic regions. We illustrate the impact of ambient temperature variations on heating requirements considering a greenhouse in Karmøy, on the coast of the Rogaland region, where most greenhouses are located in Norway. Karmøy is also close to potential industrial surplus heat sources. To this end, we use the methodology and parameters proposed by Andrews and Pearce [79]. The energy balance of a greenhouse can be represented as:

$$
\dot{Q}=U A\left(T_{G}-T_{A M}\right)+c_{p, \text { air }} \phi \rho_{\text {air }}\left(T_{G}-T_{A M}\right)-\beta S
$$

where $\dot{Q}$ corresponds to the required energy, $U$ to the heat transfer coefficient, $A$ to the wall and roof area, $c_{p, a i r}$ to the heat capacity, $\phi$ to the ventilation rate, $\rho_{\text {air }}$ to the air density, $\beta$ to the fraction of incident light absorbed by the canopy, $S$ to the total solar radiation over the greenhouse, $T_{G}$ to the greenhouse internal temperature, and $T_{A M}$ to the ambient temperature.

We assume constant heat capacity and air density, negligible solar radiation, and greenhouse temperature of $21^{\circ} \mathrm{C}$ and a surplus heat availability of $100 \mathrm{GWh} / \mathrm{a}$ available 
at an appropriate temperature, e.g., $70{ }^{\circ} \mathrm{C}$. These heating requirements can be put into perspective when considering Figure 1, which shows that $1357 \mathrm{GWh} /$ a surplus heat in the range of $60-140{ }^{\circ} \mathrm{C}$ is available from seven aluminum manufacturing installations in Norway $[15,18]$. It is also within the range of the available surplus heat for an aluminum plant reported by Skjervold [80]. With these considerations, we estimate that a 56,500 $\mathrm{m}^{2}$ greenhouse can be heated when the ambient temperature is $-8.8^{\circ} \mathrm{C}$, which was the minimum daily average temperature in Karmøy in 2018 [81]. Then, we calculate the monthly heating requirements for the $56,500 \mathrm{~m}^{2}$ greenhouse considering the monthly average temperature in Karmøy [81], with the rest of the parameters in Equation (1) kept constant.

Figure 2 illustrates that in the presented example, heating requirements during summer can be lower than a third of the requirements in the winter months. This can be an advantage when integrating such a greenhouse in an agricluster, and surplus heat can be used for different purposes along the year.

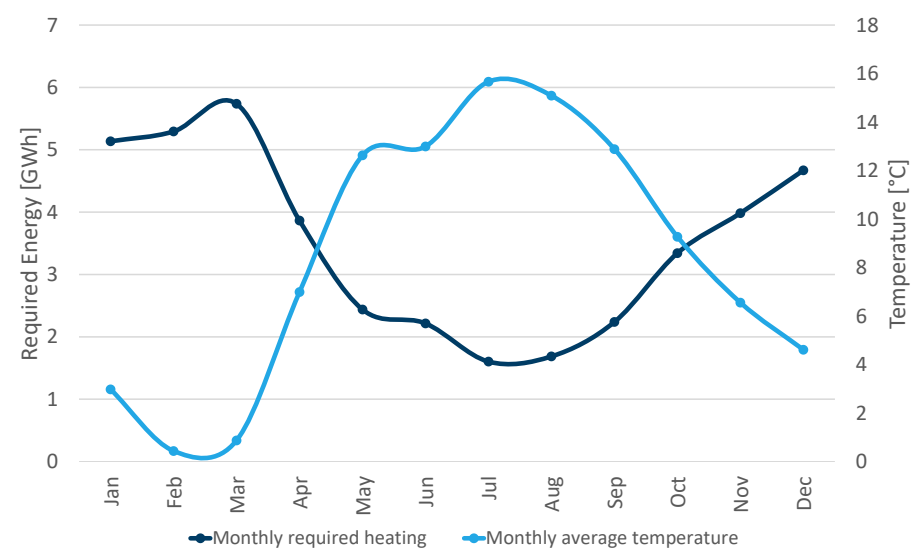

Figure 2. Estimated monthly energy consumption for a 56,500 $\mathrm{m}^{2}$ greenhouse in Karmøy, Norway, considering temperature variations in 2018.

In addition to greenhouse heating, post-processing may require heating, and low temperature heat sources may be used. Convective drying is possibly the most common process to dehydrate food, and approximately $85 \%$ of industrial applications use a variation of this technology $[82,83]$. For crops such as tomatoes, drying may be carried out with temperatures between 40 and $100{ }^{\circ} \mathrm{C}$, usually between 50 and $80{ }^{\circ} \mathrm{C}[84,85]$. Processed products such as juice and pastes should be treated to inactivate microbial activity. Thermal treatment is typical for juices, and it can be conducted by heating to $75-100{ }^{\circ} \mathrm{C}$, depending on the specific product characteristics [86,87]. Another possible post-processing application of low temperature heat is for hot filling (canning), which may require heating to temperatures around $104{ }^{\circ} \mathrm{C}$ [88].

\subsection{Fish Production}

Within the aquaculture industry, heat is mostly required for heating the building (if the tanks are within an industrial building), rearing tanks, and makeup water [89]. The required amount of heat is depending on the reared fish species, geographical location, and aquaculture method.

The potential for surplus heat utilization depends on the optimal rearing temperature of the reared fish as a first key factor. Within the fish species, we can differentiate between fishes requiring relatively low temperatures, such as salmonidae, $\left(11-12{ }^{\circ} \mathrm{C}\right.$ [90]) and high temperatures, such as tilapia $\left(28^{\circ} \mathrm{C}\right.$ [91]). While salmonidae may not require heat for long periods of the year, tilapia or comparable high temperature fishes can require a significant amount of heat, especially in Nordic weather conditions. In addition to the heating demand, the market potential of the different fish species plays a significant role. Hence, when producing in Norway for a European market using surplus heat, it is beneficial to consider fish species that: 
1. require a high rearing temperature for utilizing the majority of the surplus heat,

2. can obtain a premium price due to higher investments in land-based aquaculture, and

3. have a market in Europe but are currently produced outside Europe due to the high temperature required for rearing.

This leads to the second key factor, which is the geographical location. Heating is required in aquaculture to compensate for energy losses to the surrounding air and for heating the makeup water flow. The required heating is dependent on the ambient temperature, temperature of the makeup water flow, required temperature of the fish species, and how the rearing tanks are constructed and arranged. The rearing tank configuration corresponds to whether the tanks are within a building and the distance between the tanks and their insulation, as the heat transfer to the surroundings is governed by convection and conduction. Furthermore, pumping and fish movement may also result in an increase in temperature in the tank, resulting in reduced heating demand. As an example, the heating requirement from makeup water can be calculated as:

$$
\dot{Q}=\left(T_{T W}-T_{M W}\right) c_{p, M W} \dot{m}_{M W}
$$

in which $\dot{Q}$ corresponds to the energy required, $T_{T W}$ to the temperature in the tank, $T_{M W}$ to the temperature of the makeup water, $c_{p, M W}$ to heat capacity, and $\dot{m}_{M W}$ to the required mass flow of makeup water. The temperature of the makeup water $T_{M W}$ is dependent on the geographical location and its source. Groundwater generally has a stable temperature in the course of a year, while surface water temperature follows the seasonal variations of air temperature with a slight delay, although it will not reach values below $0{ }^{\circ} \mathrm{C}$. Hence, the water source will impact whether the heat demand of land-based aquacultures is predominantly seasonal or not.

The chosen type of aquaculture is the third key factor. In general, we can differentiate between two main types for onshore aquaculture:

1. flow through aquaculture and

2. recirculating aquaculture systems (RAS).

On the one hand, flow through aquaculture does not reuse the water leaving the tanks. This leads to a simplified process control system and, furthermore, reduces the electricity demand of the system [89]. However, as there is no recycling of used water, it may require more energy for heating the makeup water depending on the source of said water. On the other hand, RAS recycles a large share of the water, reducing the heating demand for heating freshwater, although heating may still be the largest power consumer [92]. Note that the amount of water recycled in RAS is a design parameter. Hence, the total makeup water demand of RAS may vary. It requires, however, close monitoring of the water quality and purification through the removal of fines, biological materials, ammonia, and $\mathrm{CO}_{2}$ and the addition of oxygen [93]. This results in a large electricity requirement for recirculating the water, although less water is utilized in total. As recirculating aquaculture requires more electric energy, while flow through aquaculture may require more heating, life cycle analyses are sensitive toward the type of aquaculture and the assumed heat and electricity sources $[89,94,95]$. Furthermore, the fish feed production has a major impact on the environmental impact indicators $[95,96]$. Due to the potential of improved feed utilization [95], RAS may decrease the environmental impact of feed production. However, it can be concluded that if the heat is provided from surplus heat and the electricity is decarbonized, as is the case in the Nordic Region, RAS may be on par with open net pen aquaculture with respect to greenhouse gas emission [95] while reducing the impact on other LCA factors, such as eutrophication [89] and water dependency [96].

\subsection{Seaweed Drying}

Global seaweed production is dominated by Asian countries, where it is typically used for direct human consumption or other food applications, whereas non-food applications include fertilizers, pharmaceuticals, and cosmetics. However, it is an expanding activity in 
European countries such as Norway, which has an extensive coastline, a well-established aquaculture sector, and native seaweed species recognized to have commercial value [50,97].

Large-scale cultivation of seaweed can be achieved either in monoculture or in integrated multi-trophic aquaculture (IMTA), described in Section 4.2. Depending on the species, seaweed can be cultivated in open sea or on land (e.g., tanks) and under different temperature, nutrient, current, and light conditions [98]. Open sea seaweed cultivation depends on the availability of nutrients and sunlight, which are highly seasonal (especially in the Nordic countries) and cannot be controlled. Moreover, cultivation cycles depend on the species and cultivation conditions. While some species can be harvested three or four times per year [98], others are produced annually. In Norway, ideal harvest of seaweed cultivated in open sea occurs in the summer, and the specific optimal harvest season is highly dependent on latitude.

Seaweed should be stabilized shortly after harvesting to avoid the rapid decay of the biomass and provide high-quality products to the market [99]. Therefore, efficient post-harvest processing strategies are critical to support the development of a bio-economy based on cultivated seaweed. Drying is a common method for the stabilization of wet biomass, and the most common method for seaweeds. This mass transfer process removes moisture from the product and reduces the water activity, thus preserving the product by avoiding microbial growth and limiting the rate of undesired chemical reactions. Drying can be achieved by direct sunlight or conventional convective methods, usually at temperatures $\leq 70{ }^{\circ} \mathrm{C}$. Drying temperature is a compromise between drying time and the degradation of heat sensitive material, such as protein and starch [100]. In Europe, seaweeds are typically preserved using hot-air convection drying methods at low temperature $\left(\leq 45^{\circ} \mathrm{C}\right)$ to preserve the quality of the raw material [101,102].

Due to the high water content in seaweed, $(70-95 \%)[100,103]$, energy requirements for seaweed drying are high. This lowers the sustainability of the value chain of seaweed products [104]. In this regard, Philis et al. [105] compared primary energy requirements for producing soy protein concentrate to the requirements for the production of seaweed protein concentrate, which requires drying. They found the energy requirements of the latter to be more than 11 times larger than for the soy-based concentrate. The high energy demand for seaweed processing is thus identified as one of the major bottlenecks for the development of the emerging seaweed industry in Europe [50]. Drying technologies, such as heat-pump-assisted drying [106] or superheated steam drying [107], are gaining priority in the industry (e.g., food) to increase the energy efficiency and lower the drying time and may be alternatives also for seaweed. In addition, other novel drying technologies such as microwave-assisted drying [108] or pulse combustion drying [109] could be alternatives to increase the efficiency, but should be further tested in an industrial scale. However, as mentioned in Section 2.2, direct utilization of surplus heat is preferred as it reduces exergy loss. Integrated schemes using industrial surplus heat as a secondary energy source for seaweed drying have been suggested for seaweed processing [105]. This type of strategy is suggested and discussed in Section 5.

\subsection{Insect Farming}

Human consumption of insects has been occurring for hundreds of years in certain parts of the world, and insects are a part of the regular diet even today for approximately 2.5 billion people in Africa, Asia, and Latin America [110]. The number of people eating insects is set to increase as population growth and increased global prosperity, among others, will put pressure on the prices for animal protein and the feed consumed by livestock. Insect production in the Nordic region could play a role in an increasing European market, through, e.g., reduced transportation distances, valorization of waste streams, and end-use of unutilized surplus heat. The black soldier fly (Hermetia illucens) and the yellow mealworm (Tenebrio molitor) are among the few species used for insect-based bioconversion of food waste [111]. Marine bristleworms or ragworms (Hediste diversicolor) are also being studied as a potential ingredient for aquafeed [112]. These species are capable of efficiently converting a range of low-value organic by-products into high-value protein [113] and are 
prime candidates to investigate for commercial production, as they require less feed during rearing. Therefore, these would be potential insect species for the integrated agricluster described in this paper.

The development process for the black soldier fly and yellow mealworm is fairly similar. Small worms hatch from eggs laid by an adult female insect and after a period in this larval stage the insect enters the pupal stage, where the insect matures into an adult. For these species, the growth rate is influenced by both temperature and humidity in the growth site. There is a large difference in the total life expectancy of the two species: the yellow mealworm is reported to have a total lifetime of 280 to 630 days [114], much longer than the black soldier fly. The latter typically takes around four days to hatch, 14-16 days to grow, two to three weeks in the pupation stage, and then lives between one and two weeks $[115,116]$. The typical total life expectancy is therefore between 39 and 55 days. Life cycle characteristics of the marine bristleworm, such as longevity and growth rates, vary greatly according to geographical location and population [117].

The required temperature and humidity in the insect growing environment determines the quality of surplus heat required for insect production and is therefore important to investigate. This heat demand is in the form of space heating and is hence, e.g., influenced by the outside temperature and degree of insulation of the building where the rearing takes place. It has been reported that the rearing of yellow mealworm larvae is preferred at temperatures between 26 and $30^{\circ} \mathrm{C}$ with a relative humidity of $60-70 \%$ [118]. Park et al. [119] state that the optimal temperature for mealworm growth is between 25 and $27.5^{\circ} \mathrm{C}$. The black soldier fly requires similar temperatures. Kawasaki et al. [120] state that the larvae are raised at $25-30^{\circ} \mathrm{C}$, and Chia et al. [121] claim that the optimal temperature can vary depending on feed type and might be up to $35^{\circ} \mathrm{C}$. The marine bristleworm is native in the north temperate zone of the Atlantic [117], and it can adapt to a relative wide range of temperatures $\left(0-28^{\circ} \mathrm{C}\right)$ [122].

In addition to the growing phase, the processing of insects before end-use might also require heating. Suitable processing conditions must be chosen for specific insect species to improve antimicrobial activity while reducing quality loss. High temperatures may cause protein denaturation and lipid oxidation [123]. The yellow mealworm can be processed in several different ways, including drying at $50^{\circ} \mathrm{C}$ for three days, drying at $100{ }^{\circ} \mathrm{C}$ for $200 \mathrm{~min}$, boiling in water for three minutes followed by oven drying at $60-100{ }^{\circ} \mathrm{C}$, and sundrying for two days [114]. In the case of the black soldier fly, reported processing methods are, e.g., drying at $60^{\circ} \mathrm{C}$ for $48 \mathrm{~h}$ and boiling in water for one minute followed by drying in sunlight [120]. These temperature ranges are within the available low temperature surplus heat considered in this work.

\section{Synergies between Agricluster Components}

Although surplus heat can be utilized separately in each of the mentioned processes, synergies for mass integration and energy utilization between the individual couplings are not commonly exploited. This includes both material stream integration and heat demand variations over the course of a year. In this section, we highlight specific synergies in the processes described in Section 3. This results in the proposal of a combination of all investigated processes within an agricluster fueled by the availability of low temperature surplus heat in Section 5.

\subsection{Biomass Waste for Insect Rearing}

Greenhouses and RAS systems are a source of biomass waste, and in this work, we propose its use within an agricluster as a feasible means to valorize the underutilized biomass. Due to the currently high production costs in the Nordic region, domestically grown vegetables are mainly for the fresh market. However, there can be occasional overproduction of vegetables, especially in summer. In addition, a fraction of the production is considered to be of subprime quality and unsuited for fresh consumption sale, mainly due to aesthetic reasons such as color, shape, maturity, or lesions. Considering the tomato case in Section 3.1, in Norway, tomato waste due to overproduction and subprime quality 
corresponds to approximately $200 \mathrm{t} / \mathrm{a}$, or $2 \%$ of total production [63]. Subprime tomato is predominantly used as cattle feed, whereas in other locations it may be used for landfill or destroyed. Previous efforts to produce tomato sauce using the surplus tomatoes in Norway has not been economically viable so far, mainly due to the volume, geographical dispersity, and seasonality [63].

A second source of biomass waste from greenhouses originates from pruning activities and plant disposal at the end of the season. Dias et al. [124] found that, on average, $89.7 \mathrm{~g}$ of organic waste from pruning activities is produced for each kilogram of packed tomatoes in Canada. Boulard et al. [57] found that at the end of the season, the waste corresponding to pruning and plant disposal amounted to $17 \mathrm{~kg} / \mathrm{m}^{2}$ for soilless cultivation and $13 \mathrm{~kg} / \mathrm{m}^{2}$ for soil-grown crops in France. Organic waste from pruning activities is typically landfilled. It may also be composted, but a practical difficulty is that this waste may be mixed with plastic twine and clips [57].

As mentioned in Section 3.1 greenhouse tomato is mainly for the fresh market, especially in the Nordic region. If production costs are reduced as a result of energy efficiency, and locally produced tomatoes are processed, processing would be a third source of biomass waste from greenhouses. In the case of tomato, depending on the tomato species and processing method, $2-7 \%$ of the total processed tomato is typically wasted $[63,125]$. Biowaste production may be higher for other crops [126]. Food processing may produce both solid and liquid waste. The solid portion, for example from a press cake, corresponds to skins, seeds, and fibers [126,127]. Seeds account for approximately 10\% of tomatoes and $60 \%$ of the total processing waste and are a source of protein (35\%) and fat (25\%) [125], which can be used as nutrients for insect rearing.

Insect species can become active waste management agents by converting organic wastes, sidestreams, and by-products of agricultural processes to animal proteins through a bioconversion process [123]. The yellow mealworm, black soldier fly, and marine bristleworm are capable of being fed with biomass waste. Mealworms are omnivorous and can eat all kinds of plant materials as well as animal products such as meat and feathers [118]. They have the ability to recycle plant waste materials of low quality into high-quality feed rich in energy, protein, and fat. Their diet should be balanced to about $20 \%$ protein on a dry basis, and a source of water should be provided for increased productivity [128]. As an example, the Norwegian company Invertapro [129] uses surplus vegetable and fruit biomass from the local community as feed for yellow mealworm. Black soldier fly larvae can feed quickly, from 25 to $500 \mathrm{mg}$ of fresh matter/larva/day, and on a wide range of decaying organic materials. This includes rotting fruits and vegetables, coffee bean pulp, distillers grains, fish offal, and animal manure as well as human excreta [128]. The process performance varies with the type of waste used as feed and the varying reliability and efficiency is a key challenge for black soldier fly biowaste conversion [130]. Reported values of waste reduction are, e.g., 32-36\% for fruit waste and $72 \%$ for vegetable waste on a dry weight basis [131].

Sludge from aquaculture is another potential source of biowaste in an integrated agricluster. In RAS systems, more than $98 \%$ of the particulate mater can be captured and discarded as sludge, which contains high amounts of macro- and micronutrients [112,132]. Marine bristleworms have proved to be able to recycle organic nutrients from aquaculture sludge and biogas sidestreams into high-quality proteins and lipids that can potentially serve as ingredients for aquafeeds [112]. The utilization of biowaste for insect farming may also be convenient in terms of costs, as the main cost for insect rearing is represented by the raw materials used for feeding insects [133,134].

Regulations can be a barrier preventing the use of waste as feed for insect production. In the EU, insect proteins are approved for use in fish feed [135]. However, in Europe, insects must be raised exclusively with substrates eligible as feed materials for farmed animals $[135,136]$. Similar rules apply for Norway, where only vegetable feed for insect production is allowed, and the use of sludge or kitchen or food waste is not permitted [137]. Therefore, it will be important to determine whether the surplus biomass from greenhouse 
production is classified as waste according to the existing regulatory framework. Under current EU regulations, sludge from aquaculture cannot be used as ingredient for edible animal feed [112].

\subsection{Seaweed and Insects for Fish Feed Production}

Feed for farmed fish contains protein, fat, carbohydrates, and other microingredients necessary for appropriate fish growth. Fishmeal used as fish food is produced from fresh raw fish or trimmings from food fish. Soy is also widely used as a protein source in conventional fish food. However, this crop is not grown locally in the Nordic countries, and soy used for fish feed production is imported from countries such as Brazil, which results in emissions from crop land use change as well as from transportation [105,138-140]. Other crops used for fish feed production are also grown outside the Nordic region [139].

Increasing the production efficiency and sustainability of fish feed and, thus, of aquaculture is necessary in order to meet the growing demand for an increasing population [141]. The largest share of the carbon footprint of fish feed manufacturing comes from primary ingredient production, ingredient processing, and freight, rather than feed manufacturing $[138,139]$. For this reason, developing efficient and innovative supply chains as well as sustainable alternatives for fish food ingredients is essential in order to reduce the carbon footprint of fish feed. Although seaweeds are currently not produced in sufficient volumes for large-scale commercial fish feed production, major producers of aquaculture feeds are considering them as sustainable and economically viable sources of protein and essential omega-3 long chain fatty acids for fish food production [138]. Insects are not produced at large scale in Nordic countries either. However, as mentioned earlier in this paper, some national regulations already allow the use of insects as fish food (e.g., [137]).

To maintain optimal performance indicators, substitution of traditional fish food with insect- or seaweed-based fish food may be partial for most fish species [128,142]. Feeding studies indicate that the palatability of insect meals is good and can partially replace fishmeal in the diets of fish species [141]. Moreover, the aroma and texture of fish does not change on feeding with some insect species such and black soldier fly larvae. However, depending on the insect and fish species, insect meal may require supplementation for optimal fish growth. Therefore, levels of insect meal inclusion need are being studied to assure proper fish food performance [128,141,142].

Black soldier fly larvae, mealworm, and silkworm are adept at accumulating lipids and can be a protein-rich resource in the fish feed industry. While the amount of crude protein in black soldier fly larvae varies between $40-44 \%$, the amount of fat and fatty acid composition depends on the diet, going from $15 \%$ for larvae fed on poultry manure to up to $40 \%$ for larvae fed on oil-rich food waste [128]. The protein content of mealworms (47-60\%) depends on diet. Fat content varies from 31 to $43 \%$. Black soldier fly meal has been tested experimentally as a partial substitute for fishmeal in different fish species such as channel catfish, blue tilapia, rainbow trout, Atlantic salmon, and turbot. Belghit et al. [141] used both protein meal and oil from black soldier fly larvae as part of Atlantic salmon diet. Fresh and dried mealworms have been found to be an acceptable alternate protein source for fish species such as the African catfish, gilthead sea bream, rainbow trout, and European sea bass. For both insect species, replacement of fishmeal without affecting performance ranged between 25 and $60 \%$, depending on factors such as the fish species and method of insect meal preparation [128,141]. Belghit et al. [142] replaced fishmeal entirely with black soldier fly larvae meal in the diets of Atlantic salmon without negative effects on growth performance, feed utilization, or sensory qualities of the fillet.

As in the case of insect protein, seaweed protein can substitute soy protein for fish food production. However, substitution leads to an environmental trade-off. Philis et al. [105] found out that while the seaweed protein concentrate value chain has near-zero mineral phosphorous consumption by using natural occurring marine phosphorous compared to $25.75 \mathrm{~kg}$ of mineral phosphorous per tonne of soy-based concentrate, the primary energy demand of the seaweed value chain is 11.68 times larger than for the soy-based concentrate. Utilizing surplus heat for drying reduces the factor to 2.3 as the energy for 
drying corresponds to $83 \%$ of the primary energy demand. Seaweed may represent not only a source of biomass for insect rearing but an alternative for improving the nutritional composition of insect feed by introducing marine nutrients. Liland et al. [143] demonstrated that black soldier fly larvae can be successfully grown on media containing up to $50 \%$ brown algae (A. nodosum). Based on these results, Belghit et al. [142] showed that Atlantic salmon can be successfully fed with black soldier fly larvae grown on media partially containing brown seaweed [141,142]. These results support the idea of integrating seaweed production with fish and insect rearing.

Integrated multitrophic aquaculture (IMTA) has also been proposed as a solution to mitigate the negative effects of fish farming wastes by utilizing excess nutrients for marine plant production. IMTA combines the cultivation of fed aquaculture species (e.g., finfish), with organic extractive aqualculture species (e.g., shellfish) and inorganic extractive aquaculture species (e.g., seaweed) for a balanced ecosystem management approach [144]. Within IMTA, fish production is moved to the sea. Hence, this option is not further explored in this paper, although it is an additional potential integration alternative to evaluate in the proposed agricluster.

\subsection{Aquaponics for Combined Greenhouse and Fish Growing}

Aquaponics integrates greenhouses through hydroponics and recirculating aquaculture systems into a single system [145]. Its key aim is to consider the waste of one process as the input to another process, i.e., the waste of fishes as fertilizer for the plants in greenhouses. This leads to an overall reduction in waste and water usage. In addition, it reduces the need of energy-intensive inputs, such as fertilizers from fossil sources, which are among the highest-emitting agricultural categories [7,146]. However, aquaponics comes at the cost of higher investment costs, compromises between optimal condition for fish rearing and greenhouse production, and a more complicated control system due to the necessity of monitoring the water quality. Palm et al. [147] provide a detailed review of different system designs and scales of aquaponics. Aquaponic systems can be coupled, that is the process water flows from the aquaculture to the hydroponics and back, or decoupled in which the two processes do not transfer mass directly between each other but through intermediate processes [148]. Figure 3 illustrates the concepts of coupled and decoupled aquaponics.

The advantage of decoupled systems is to avoid compromises between the conditions in hydroponics and aquacultures. It allows operating both RAS and hydroponics at the respective optimal conditions. This is achieved through sludge treatment via, e.g., anaerobic digestion for improved utilization of the solid waste from fish production [149] and distillation for concentrating valuable nutrients in the stream leaving the hydroponics unit. The former also produces biogas as side product. Furthermore, it is feasible to have an additional fertilizer feed to the greenhouse production. However, decoupled aquaponics requires further investments in the intermediate processes and improved control structures. Growth and nutrient models have also been designed for aquaponic systems, simplifying the design process of new installations and the analysis of the behaviour of individual plant-fish combinations [150].

The overall heat requirement is dependent on the design of the aquaponics system. In general, the heat loss of the greenhouse to the environment is equal to the heat loss in standalone greenhouses due to the absence of changes in the greenhouse area. The amount of makeup water for RAS may change depending on the recirculation of water from the greenhouse. This also translates into a variation of the heat demand of aquaponics for heating the makeup water flow. Furthermore, if distillation is utilized for improving the nutrient concentrations in both hydroponics and RAS [148], additional heat is required for operating the distillation unit. However, it can be said that a large share of the heat demand of a decoupled aquaponics systems is seasonal if surface water is used as makeup water. This stems from the fact that heat is required for both space and water heating. Both demands are higher in the winter than in the summer due to lower outside temperatures. The integration of aquaculture and greenhouse via aquaponics is already shown to work on small scale [151]. Furthermore, the project Aquaponics NOMA showed that 
aquaponics is also feasible with warm water fishes in the Nordic region if additional heat is supplied [152]. Aquaponics can be also seen in the context of circular economy and urban rooftop farming [153]. As an example, The BIGH project uses a coupled aquaponics approach with $2000 \mathrm{~m}^{2}$ of tanks and a greenhouse on top of a food market.

a) Decoupled aquaponics

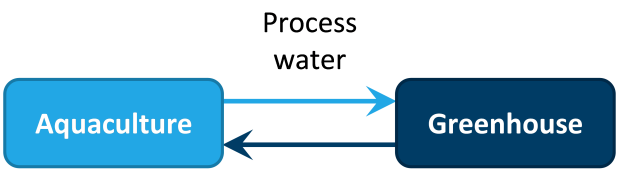

b) Coupled (multi-loop) aquaponics

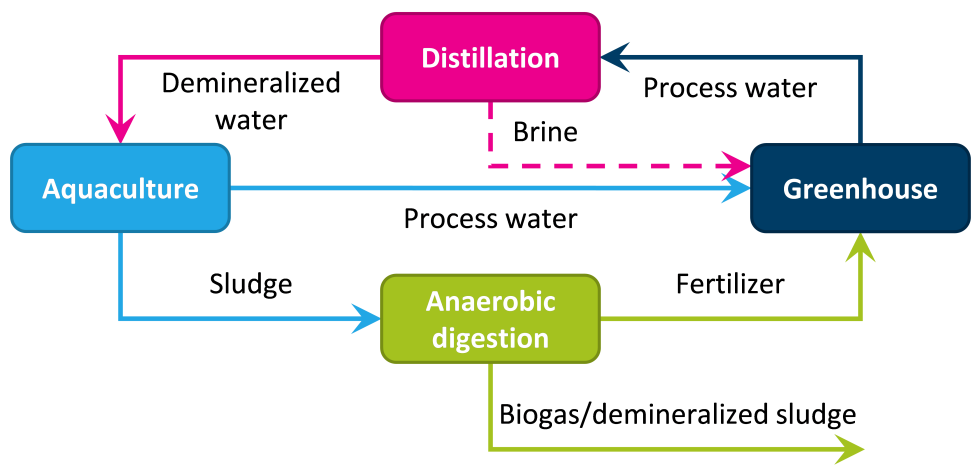

Figure 3. Illustration of (a) coupled and (b) decoupled (multi-loop) aquaponics, adopted from [148].

\section{Improved Utilization of Surplus Thermal Energy in an Integrated Agricluster}

The previously described synergies between the individual processes may furthermore be exploited in a so-called agricluster in which further coupling between the individual processes is introduced. Here, the enabler for clustering is not the usage of a common utility infrastructure, a source of raw material or manufacturing of related products, but the availability of surplus heat. Long transport distances increase overall energy requirements. A surplus energy-driven agricluster allows the local production of food, such as vegetables and fish, that can normally not be produced in Nordic climates due to the low outside temperature, especially during winter months (e.g., see Figure 2).

Figure 4 shows the key energy and mass links in such an integrated agricluster based on the material stream connections described in Section 4. The key integration factors are the use of aquaponics for food production. Insect rearing and seaweed drying are both seen mainly as supplementary to reduce the need for external feed for aquaculture. However, insect rearing is still enabled through both greenhouse production and seaweed drying for providing the required feed. The potential use of sludge from aquaculture as potential feed for insect rearing is not illustrated due to the current regulatory constraints mentioned in Section 4.1. In addition, it is feasible to produce biofuels or biochemicals from seaweed (e.g., bioethanol and liquid fertilizer [154]) as well as feed for land animals from insects depending on the scale of the insect rearing production. Further quantitative analyses for a specific site are required to be able to answer whether additional feed production from insects is feasible.

The overall scaling of the individual processes is dependent on the crops grown in the greenhouse, the proposed fish, and the potential for seaweed production in the vicinity of the cluster. In addition, site specific characteristics, such as outside temperature or available space, may impact the chosen processes. This makes it complex to obtain an overview of the overall capital and operational expenses and, hence, the profitability of such an agricluster without loss of generality, which is the aim of this paper. However, several generalized conclusions can be drawn: 
1. The integration of the individual processes leads to an improved utilization of the available resources by considering the waste of one process as the resource for another.

2. Integrating the individual processes into a single agricluster allows a reduction in transport costs and emissions as less input to the system is required. This is specifically relevant for substitution of emission-intensive feedstock such as soy-based fish feed or fishmeal.

3. Exploiting synergies, nutrient cycling, as well as mass and energy integration can lead to an efficient utilization of by-products and waste reduction, enabling the reduction of the environmental and climate footprint of the food production system.

4. The majority of the considered food production processes require more heat in the winter than in the summer, as the heat is utilized for space or water heating. As an exception, seaweed drying, which is highly energy intensive, requires heat in the summer due to the harvest season and may balance the overall energy demand.

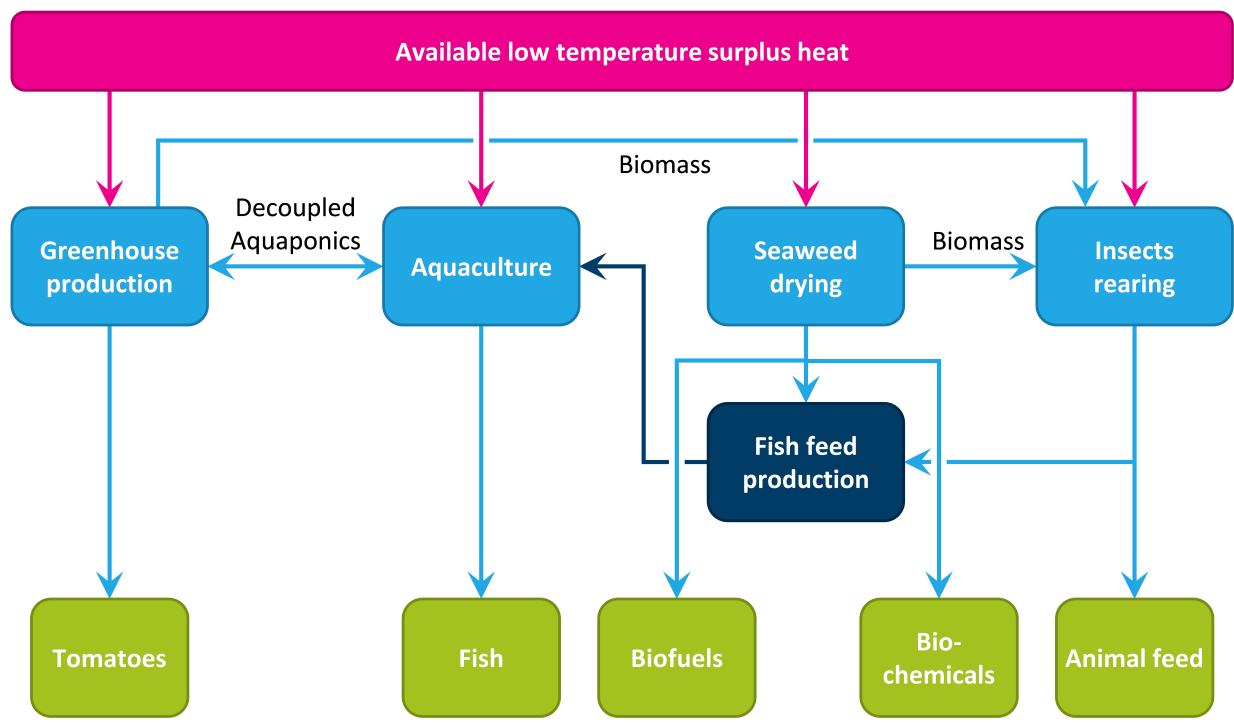

Figure 4. Proposal for an agricluster based on surplus heat from industry, highlighting the mass streams interconnections between the different processes.

Nonetheless, there are also challenges associated with an integrated food production cluster. One major disadvantage compared to existing production technologies is related to the costs. Specifically, the integration of hydroponics and RAS into aquaponics requires a more complex system and control of the individual variables, resulting in increased capital expenses [148]. Therefore, it is difficult to obtain a detailed estimate of corresponding costs and, hence, profitability of the coupling of RAS and hydroponics. These generally depend on the specific design. Furthermore, Turnšek et al. [155] highlight that existing estimates for payback periods have to be taken with caution due to the large variety of combinations of fish and plant species. Specifically, estimates made 10 years ago were proven to not be valid. Similarly, the production of insects and drying of seaweed using surplus heat is still in its infancy in Europe. In combination with potential regulatory barriers for utilizing, e.g., biomass waste as insect feed or insect proteins and seaweed as fish feed, this infancy may result in delays for developing an integrated agricluster. However, the first steps toward a regulation that allows for this type of use have already been taken [135,137].

Another factor to consider is the effect of heat export on the industrial actor, whose presence is a prerequisite for the establishment of the agricluster we propose. In the case of an aluminum production plant, it would be necessary to recover heat from the off-gas to meet the temperature needs of the cluster. The off-gas channels are located centrally in an aluminum plant and free space is often limited, which could make heat exchanger installation challenging. In addition, heat recovery will introduce an additional resistance in the duct system, which could lead to increased overall pressure drop and 
fan work [156]. This, along with possible heat exchanger maintenance requirements, can potentially increase the operational costs of the plant.

A critical aspect to consider for the integration and operation of such a cluster is production seasonality. Light and nutrient availability can be controlled in greenhouses, RAS, and closed insect production facilities, although this would be at the cost of potentially increased electricity demand. However, each of the proposed processes has different rearing or growth periods, mainly depending on the selected species or crop. This will of course affect the production of "waste" that is used as a "resource" in the other processes. Different species and crop combinations will need specific material and integration and coupling strategies. Decoupled aquaponics partially solves this problem between greenhouse and fish rearing, as discussed in Section 4.3. Similar schemes may be proposed for the other interactions. A common aspect among greenhouses, RAS, and closed insect production facilities is that heating requirements are tightly determined by the outside temperature, which is more or less cyclical. Thermal energy storage solutions can be considered to overcome the potential mismatch between surplus heat availability and heat demand in the agricluster. In this regard, phase change materials (PCM), which release or absorb energy while changing phase, are being studied as a potential solution within the processing and food industry for the recovery of surplus heat, especially for daytime temperature variations $[157,158]$. With respect to seasonal variations, there is a peak in the winter and significantly lower heating requirements in the summer. Conveniently, as mentioned in Section 3.3, the seaweed harvesting season corresponds to the season with lower heating requirements of the rest of the proposed agricluster components. Therefore, in this case, the cyclical nature of production and heat requirements is, in fact, an enabler for the agricluster.

Finally, it should be mentioned that adequate and sufficient funding instruments, in addition to the ones mentioned in Section 1, should be set in place. Investment finance is typically insufficient to meet demand and meets only a relatively small share of total agricultural investment needs [146]. In addition, there is a need for investment in R\&I in the field of low temperature surplus heat utilization and integrated food production systems, which would result in improving knowledge and generating innovations.

\section{Conclusions and Future Work}

In this paper, we investigated the utilization of surplus heat for sustainable food production. The utilization of industrial surplus heat in an agricluster is particularly interesting in the Nordic region, where fresh fruits and vegetables are generally imported due to the low outside temperature during most of the year. In addition, the local production of food may result in a reduction in GHG emissions and the environmental impact of food production due to the large share of renewable energy in the electricity sector of the Nordic region. Although there are examples of industrial surplus heat utilization in fish and greenhouse production, there is still a large potential for improved utilization of the resources through integration of the individual processes. The proposed agricluster allows, correspondingly, an improved utilization of available resources and energy by accounting for the seasonality of the different processes. Moreover, through the novel suggested integration of waste heat and biomass, the agricluster concept may be contextualized as a sustainable industry supercluster that uses industrial waste heat to produce several kinds of human food sustainably (in this work, the proposed foods are tomatoes and warm water fish).

Strategies for proper sizing of the individual processes is a direction for future work and may be based on the local availability of existing sources for surplus heat as well as demand for individual products. These strategies could also include methods to identify the economic sustainability of a proposed agricluster project. Ideally, these methods should include alternative uses for the industrial waste heat, estimates for equipment and construction costs, and should also consider the local market conditions and regulations. Local regulations are particularly important in order to realize an agricluster, as environmental policies and legislation supporting the recovery of surplus heat and the use of 
sidestreams (such as "biowaste") as feedstocks in the food industry are required to enable the development of agriclusters as proposed in this paper.

Author Contributions: Conceptualization, J.S., A.R.-L. and G.D.; methodology, A.R.-L., J.S., V.T.S. and T.S.N.; validation, J.S., A.R.-L., V.T.S. and T.S.N.; formal analysis, J.S., A.R.-L., V.T.S., G.D. and T.S.N.; investigation, A.R.-L., J.S., V.T.S., G.D. and T.S.N.; writing-original draft preparation, J.S., A.R.L., V.T.S. and T.S.N.; writing-review and editing, J.S., A.R.-L., V.T.S., G.D. and T.S.N.; visualization, J.S., A.R.-L.; supervision, A.R.-L.; project administration, A.R.-L. and J.S. All authors have read and agreed to the published version of the manuscript..

Funding: This publication has been funded by HighEFF-Centre for an Energy Efficient and Competitive Industry for the Future, an 8-years Research Centre under the FME-scheme (Centre for Environment-friendly Energy Research, 257632/E20). The authors gratefully acknowledge the financial support from the Research Council of Norway and user partners of HighEFF.

Conflicts of Interest: The authors declare no conflict of interest.

\author{
Abbreviations \\ The following abbreviations are used in this manuscript: \\ CAP Common Agricultural Policy \\ CHP combined heat and power \\ EAFRD European Agricultural Fund for Rural Development \\ GHG greenhouse gas \\ IMTA integrated multitrophic aquaculture \\ PCM phase change materials \\ RAS recirculating aquaculture system
}

\title{
References
}

1. European Commission. A European Green Deal; European Commission: Brussels, Belgium , 2019.

2. EU. Directive (EU) 2018/2002 of the European Parliament and of the Council of 11 December 2018 amending Directive 2012/27/EU on energy efficiency. Off. J. Eur. Union 2018, L328, 210-230.

3. European Commission. Circular Economy Action Plan; European Commission : Brussels, Belgium, 2020.

4. Muscio, A.; Sisto, R. Are Agri-Food Systems Really Switching to a Circular Economy Model? Implications for European Research and Innovation Policy. Sustainability 2020, 12, 5554. [CrossRef]

5. European Commission. Farm to Fork Strategy for a Fair, Healthy and Environmentally-Friendly Food System; European Commission: Brussels, Belgium , 2020.

6. Fu, C.; Anantharaman, R.; Jordal, K.; Gundersen, T. Thermal efficiency of coal-fired power plants: From theoretical to practical assessments. Energy Convers. Manag. 2015, 105, 530-544. [CrossRef]

7. Woods, J.; Williams, A.; Hughes, J.K.; Black, M.; Murphy, R. Energy and the food system. Philos. Trans. R. Soc. B Biol. Sci. 2010, 365, 2991-3006. [CrossRef] [PubMed]

8. Kullmann, F.; Markewitz, P.; Stolten, D.; Robinius, M. Combining the worlds of energy systems and material flow analysis: A review. Energy Sustain. Soc. 2021, 11, 13. [CrossRef]

9. Edwards, C.A. The importance of integration in sustainable agricultural systems. Agric. Ecosyst. Environ. 1989, $27,25-35$. [CrossRef]

10. Jurgilevich, A.; Birge, T.; Kentala-Lehtonen, J.; Korhonen-Kurki, K.; Pietikäinen, J.; Saikku, L.; Schösler, H. Transition towards Circular Economy in the Food System. Sustainability 2016, 8, 69. [CrossRef]

11. Woolley, E.; Luo, Y.; Simeone, A. Industrial waste heat recovery: A systematic approach. Sustain. Energy Technol. Assess. 2018, 29, 50-59. [CrossRef]

12. Ammar, Y.; Joyce, S.; Norman, R.; Wang, Y.; Roskilly, A.P. Low grade thermal energy sources and uses from the process industry in the UK. Appl. Energy 2012, 89, 3-20. [CrossRef]

13. Forman, C.; Muritala, I.K.; Pardemann, R.; Meyer, B. Estimating the global waste heat potential. Renew. Sustain. Energy Rev. 2016, 57, 1568-1579. [CrossRef]

14. Johnson, I.; Choate, W.T.; Davidson, A. Waste Heat Recovery. Technology and Opportunities in U.S. Industry; Technical Report; EERE Publication and Product Library: Laurel, MD, USA, 2008 [CrossRef]

15. Sollesnes, G.; Helgerud, H. Potensialstudie for Utnyttelse av Spillvarme fra Norsk Industri [Study of the Potential for Utilization of Surplus Heat from Norwegian Industry]; Technical Report; ENOVA: Oslo, Norway , 2009.

16. Grip, C.E. Steel and sustainability: Scandinavian perspective. Ironmak. Steelmak. 2005, 32, 235-241. [CrossRef] 
17. Regjeringen (Norwegian Government). Business and Industry in Norway-The Metals Industry; Regjeringen (Norwegian Government): Oslo, Norway, 2001.

18. Norsk Industri. Om Aluminiumsbransjen [About the Aluminum Industry]; Norsk Industri: Oslo, Norway, 2021.

19. Cullen, J.M.; Allwood, J.M. Mapping the Global Flow of Aluminum: From Liquid Aluminum to End-Use Goods. Environ. Sci. Technol. 2013, 47, 3057-3064. [CrossRef]

20. Saevarsdottir, G.; Kvande, H.; Welch, B.J. Aluminum Production in the Times of Climate Change: The Global Challenge to Reduce the Carbon Footprint and Prevent Carbon Leakage. JOM 2020, 72, 296-308. [CrossRef]

21. Nowicki, C.; Gosselin, L. An overview of opportunities for waste heat recovery and thermal integration in the primary aluminum industry. JOM 2012, 64, 990-996. [CrossRef]

22. Bouhabila, E.; Næss, E.; Einejord, V.; Kristjansson, K. An innovative compact heat exchanger solution for aluminium off-gas cooling and heat recovery. In TMS Light Metals; Springer: Cham, Switzerland, 2013; pp. 793-797.

23. de Gromard, A.; Lim, C.; Bouhabila, E.; Cloutier, B.; Frainais, M. Development on electrolytic cell gas cooling. In TMS Light Metals; Springer: Berlin/Heidelberg, Germany, 2014; pp. 623-628.

24. Verbraak, P.; Turco, T.; Klut, P.; Dupon, E.; Engel, E. Pot gas cooling technologies. In TMS Light Metals; The Minerals, Metals \& Materials Society (TMS) Light Metals, Light Metals Digital Library: Pittsburgh, PA, USA, 2014; pp. $635-639$.

25. Sørhuus, A.; Wedde, G.; Rye, K.; Nyland, G. Increased energy efficiency and reduced HF emissions with new heat exchanger. In TMS Light Metals; The Minerals, Metals \& Materials Society (TMS) Light Metals, Light Metals Digital Library: Pittsburgh, PA, USA, 2010; pp. 249-254.

26. Al Qassab, H.; Mohd, S.; Wedde, G.; Sørhuus, A. Hex retrofit enables smelter capacity expansion. In TMS Light Metals; The Minerals, Metals \& Materials Society (TMS) Light Metals, Light Metals Digital Library: Pittsburgh, PA, USA, 2012; pp. 815-820.

27. Sørhuus, A.; Ose, S.; Nilsen, B. Possible use of $25 \mathrm{MW}$ thermal energy recovered from the potgas at Alba line 4 . In TMS Light Metals; Springer: Berlin/Heidelberg, Germany, 2015; pp. 631-636.

28. Cascella, F.; Gaboury, S.; Sorin, M.; Teyssedou, A. Proof of concept to recover thermal wastes from aluminum electrolysis cells using Stirling engines. Energy Convers. Manag. 2018, 172, 497-506. [CrossRef]

29. Barzi, Y.M.; Assadi, M.; Parham, K. A waste heat recovery system development and analysis using ORC for the energy efficiency improvement in aluminium electrolysis cells. Int. J. Energy Res. 2018, 42, 1511-1523. [CrossRef]

30. Law, R.; Harvey, A.; Reay, D. Opportunities for low-grade heat recovery in the UK food processing industry. Appl. Therm. Eng. 2013, 53, 188-196. [CrossRef]

31. Oluleye, G.; Jobson, M.; Smith, R. A hierarchical approach for evaluating and selecting waste heat utilization opportunities. Energy 2015, 90, 5-23. [CrossRef]

32. Oluleye, G.; Jiang, N.; Smith, R.; Jobson, M. A novel screening framework for waste heat utilization technologies. Energy 2017, 125, 367-381. [CrossRef]

33. Kavvadias, K.C.; Quoilin, S. Exploiting waste heat potential by long distance heat transmission: Design considerations and techno-economic assessment. Appl. Energy 2018, 216, 452-465. [CrossRef]

34. Fang, H.; Xia, J.; Zhu, K.; Su, Y.; Jiang, Y. Industrial waste heat utilization for low temperature district heating. Energy Policy 2013, 62, 236-246. [CrossRef]

35. Fitó, J.; Ramousse, J.; Hodencq, S.; Wurtz, F. Energy, exergy, economic and exergoeconomic (4E) multicriteria analysis of an industrial waste heat valorization system through district heating. Sustain. Energy Technol. Assess. 2020, 42, 100894. [CrossRef]

36. Naturårdsverket. Goda möjligheter Med Spillvärme-En Utvärdering av LIP-Finansierade Spillvärmeprojekt; Technical Report; Naturvårdsverket: Stockholm, Sweden, 2005.

37. SSB (Statistics Norway). Karmøy, Rogaland, Befolkning (Population of Karmøy, Rogaland). Available online: www.ssb.no/ko mmunefakta/karmoy (accessed on 27 August 2021).

38. SSB (Statistics Norway). Sunndal, Møre og Romsdal, Befolkning (Population of Sunndal, Møre og Romsdal). Available online: www.ssb.no/kommunefakta/sunndal (accessed on 27 August 2021).

39. Lauterbach, C.; Schmitt, B.; Jordan, U.; Vajen, K. The potential of solar heat for industrial processes in Germany. Renew. Sustain. Energy Rev. 2012, 16, 5121-5130. [CrossRef]

40. Saha, B.K.; Chakraborty, B.; Dutta, R. Estimation of waste heat and its recovery potential from energy-intensive industries. Clean Technol. Environ. Policy 2020, 22, 1795-1814. [CrossRef]

41. Gerres, T.; Chaves Ávila, J.P.; Llamas, P.L.; San Román, T.G. A review of cross-sector decarbonisation potentials in the European energy intensive industry. J. Clean. Prod. 2019, 210, 585-601. [CrossRef]

42. Miljøgartneriet AS. Available online: https://miljogartneriet.no/hjem (accessed on 15 April 2021).

43. Industrial Symbiosis Grows Tomatoes. Available online: http://advantage-environment.com/food/industrial-symbiosis-grows -tomatoes/ (accessed on 24 November 2020).

44. Elleholms Tomatodling AB. Miljö (Environment). Available online: www.elleholmstomater.se/miljo/ (accessed on 15 April 2021).

45. Pettersen, T.R.; Dæhlin, E.; Eidem, P.A.; Berglihn, O.T. Investigating the Potential for Increased Energy Utilisation and Reduced $\mathrm{CO}_{2}$ Emissions at Mo Industrial Park. Energies 2020, 13, 4627. [CrossRef]

46. Mo Industripark AS. Bedrifter i Mo Industripark. Available online: https://www.mip.no/mo-industripark/bedrifter-i-mo-ind ustripark (accessed on 15 April 2021). 
47. Tjeldbergodden Utvikling AS (TBU). Bioparken. Available online: https://www.tbu.no/en/bioparken/ (accessed on 15 April 2021).

48. Eramet Norway. Eramet Norway Kvinesdal. Available online: https://eramet.no/var-virksomhet/kvinesdal/ (accessed on 15 April 2021).

49. HS Orka. Resource Park. Available online: www.resourcepark.is/companies/ (accessed on 15 April 2021).

50. Barbier, M.; Araújo, R.; Rebours, C.; Jacquemin, B.; Holdt, S.L.; Charrier, B. Development and objectives of the PHYCOMORPH European Guidelines for the Sustainable Aquaculture of Seaweeds (PEGASUS). Bot. Mar. 2020, 63, 5-16. [CrossRef]

51. Lupton, D.; Turner, B. Food of the Future? Consumer Responses to the Idea of 3D-Printed Meat and Insect-Based Foods. Food Foodways 2018, 26, 269-289. [CrossRef]

52. FAO. Tomato. Available online: www.fao.org/land-water/databases-and-software/crop-information/tomato/en/ (accessed on 9 September 2019).

53. Verheul, M.J.; Maessen, H.; Grimstad, S. Optimizing a Year-Round Cultivation System of Tomato Under Artificial Light; KU Leuven: Leuven, Belgium, 2012; pp. 389-394. [CrossRef]

54. Li, Y.; Niu, W.; Dyck, M.; Wang, J.; Zou, X. Yields and Nutritional of Greenhouse Tomato in Response to Different Soil Aeration Volume at two depths of Subsurface drip irrigation. Sci. Rep. 2016, 6, 1-10 . [CrossRef]

55. Bævre, O.A.; Bø, L.Ø.; Jelsa, R.; Randeberg, E.; Verheul, M. Energi til Norsk Veksthusnæring-Bruk av Naturgass som Energibærer og $\mathrm{CO}_{2}$-Kilde; Bioforsk Vest: Ås, Norway, 2006.

56. Shen, Y.; Wei, R.; Xu, L. Energy Consumption Prediction of a Greenhouse and Optimization of Daily Average Temperature. Energies 2018, 11, 65. [CrossRef]

57. Boulard, T.; Raeppel, C.; Brun, R.; Lecompte, F.; Hayer, F.; Carmassi, G.; Gaillard, G. Environmental impact of greenhouse tomato production in France. Agron. Sustain. Dev. 2011, 31, 757-777. [CrossRef]

58. SSB. Increased Vegetable Production, 2017. Available online: www.ssb.no/en/jord-skog-jakt-og-fiskeri/artikler-og-publikasjon er/increased-vegetable-production (accessed on 9 September 2019).

59. Landbruksdirektoratet. Markedsrapport 2018. Vurdering av Markedene for Norske Landbruksvarer; Technical Report; Landbruksdirektoratet Avdeling Handel og Industri: Oslo, Norway, 2019.

60. OFG. Totaloversikten 2018-Opplysningskontoret for Frukt og Grønt; Technical Report; Opplysningskontoret for Frukt og Grønt: Langhus, Norway, 2019.

61. Åsbø, B. Import tomater 2018. Available online: https:/ /www.grontprodusentene.no/statistikk/2018 (accessed on 27 August 2021).

62. Ridder, M. Annual Volume of Tomatoes Imported into Norway from 2010 to 2018. Available online: https://www.statista.com/s tatistics /646301/annual-import-volume-of-tomatoes-into-norway (accessed on 27 August 2021).

63. Løvdal, T.; Van Droogenbroeck, B.; Eroglu, E.C.; Kaniszewski, S.; Agati, G.; Verheul, M.; Skipnes, D. Valorization of Tomato Surplus and Waste Fractions: A Case Study Using Norway, Belgium, Poland, and Turkey as Examples. Foods 2019, 8, 229. [CrossRef] [PubMed]

64. Van Kvitvær, A.; Verheul, M.; Leeuwen, G. Muligheter til Dyrking av Eksotiske Veksthusgrønnsaker i Norge; Technical Report; NIBIO: Særheim, Norway , 2017.

65. De León-Sifuentes, W.E. Evaluación Ambiental de la Producción de Tomate Bajo Condiciones Protegidas en las Palmas de Gran Canaria, España, Mediante la Utilización de la Metodología del Análisis del ciclo de Vida (ACV). Ph.D. Thesis, Universidad Autónoma de Barcelona, Barcelona, Spain, 2009.

66. Ministerio de Agricultura, Pesca y Alimentación (MAPA, Ministry of Agriculture, Fisheries and Food). Encuesta sobre Superficies y Rendimientos Cultivos (ESYRCE); Resumen de resultados España y Comunidades Autónomas MAPA: Madrid, Spain, 2018 .

67. Heuvelink, E. (Ed.) Tomatoes; Volume 27 of Agriculture Series Crop Production Science in Horticulture, 2nd ed.; CABI: Wallingford, UK, 2018; Volume 27.

68. Peet, M.; Welles, G.H. Greenhouse tomato production. In Tomatoes (Crop Production Science in Horticulture); Heuvelink, E., Ed.; Wageningen University: Wageningen, The Netherlands, 2005.

69. Orozco, L.; Rico-Romero, L.; Escartín, E.F. Microbiological Profile of Greenhouses in a Farm Producing Hydroponic Tomatoes. J. Food Prot. 2008, 71, 60-65. [CrossRef]

70. Pérez Neira, D.; Soler Montiel, M.; Delgado Cabeza, M.; Reigada, A. Energy use and carbon footprint of the tomato production in heated multi-tunnel greenhouses in Almeria within an exporting agri-food system context. Sci. Total Environ. 2018, 628-629, 1627-1636. [CrossRef]

71. Hille, J.; Solli, C.; Refsgaard, K.; Krokann, K.; Berglann, H. Environmental and Climate Analysis for the Norwegian Agriculture and Food Sector and Assessment of Actions; Norwegian Agricultural Economics Research Institute: Bergen, Norway, 2012 .

72. Bosona, T.; Gebresenbet, G. Life cycle analysis of organic tomato production and supply in Sweden. J. Clean. Prod. 2018, 196, 635-643. [CrossRef]

73. Theurl, M.C.; Haberl, H.; Erb, K.H.; Lindenthal, T. Contrasted greenhouse gas emissions from local versus long-range tomato production. Agron. Sustain. Dev. 2014, 34, 593-602. [CrossRef]

74. Verheul, M.J.; Thorsen, S.M. Klimagassregnskap for Norske Veksthusprodukter; Bioforsk: Særheim, Norway, 2010 .

75. Karlsson, H. Seasonal Vegetables: An Environmental Assessment of Seasonal Food. Master's Thesis, Norwegian University of Life Sciences, Ås, Norway, 2012. 
76. Stoessel, F.; Juraske, R.; Pfister, S.; Hellweg, S. Life Cycle Inventory and Carbon and Water FoodPrint of Fruits and Vegetables: Application to a Swiss Retailer. Environ. Sci. Technol. 2012, 46, 3253-3262. [CrossRef] [PubMed]

77. Lam, W.Y.; van Zelm, R.; Benítez-López, A.; Kulak, M.; Sim, S.; King, J.M.H.; Huijbregts, M.A.J. Variability of Greenhouse Gas Footprints of Field Tomatoes Grown for Processing: Interyear and Intercountry Assessment. Environ. Sci. Technol. 2018, 52, 135-144. [CrossRef]

78. González, A.D.; Frostell, B.; Carlsson-Kanyama, A. Protein efficiency per unit energy and per unit greenhouse gas emissions: Potential contribution of diet choices to climate change mitigation. Food Policy 2011, 36, 562-570. [CrossRef]

79. Andrews, R.; Pearce, J. Environmental and economic assessment of a greenhouse waste heat exchange. J. Clean. Prod. 2011, 19, 1446-1454. [CrossRef]

80. Skjervold, V. Status on Surplus Heat Database 2017. Available online: https://sintef.brage.unit.no/sintef-xmlui/bitstream/han dle/11250/2670510/D4.2_2017.01+surplus+heat+database+status.pdf?sequence=1 (accessed on 27 August 2021).

81. MET (Norwegian Meteorological Institute) Norway. eKlima. Available online: eklima.met.no (accessed on 27 August 2021).

82. Mujumdar, A. Principles, classification and selection of dryers. In Handbook of Industrial Drying; CRC Press: Boca Raton, FL, USA, 2007.

83. Atuonwu, J.C.; Jin, X.; van Straten, G.; van Deventer Antonius, H.C.; van Boxtel, J. Reducing energy consumption in food drying: Opportunities in desiccant adsorption and other dehumidification strategies. Procedia Food Sci. 2011, 1, 1799-1805. [CrossRef]

84. Khazaei, J.; Chegini, G.R.; Bakhshiani, M. A Novel Alternative Method for Modeling the Effects of Air Temperature and Slice Thickness on Quality and Drying Kinetics of Tomato Slices: Superposition Technique. Dry. Technol. 2008, 26, 759-775. [CrossRef]

85. Reinoso Moreno, J.; Pinna-Hernández, G.; Fernández Fernández, M.; Sánchez Molina, J.; Rodríguez Díaz, F.; López Hernández, J.; Acién Fernández, F. Optimal processing of greenhouse crop residues to use as energy and $\mathrm{CO}_{2}$ sources. Ind. Crop. Prod. 2019, 137, 662-671. [CrossRef]

86. Jayathunge, K.G.L.R.; Stratakos, A.C.; Delgado-Pando, G.; Koidis, A. Thermal and non-thermal processing technologies on intrinsic and extrinsic quality factors of tomato products: A review. J. Food Process. Preserv. 2019, 43, e13901. [CrossRef]

87. Kips, L.; De Paepe, D.; Van Meulebroek, L.; Van Poucke, C.; Larbat, R.; Bernaert, N.; Van Pamel, E.; De Loose, M.; Raes, K.; Van Droogenbroeck, B. A novel spiral-filter press for tomato processing: Process impact on phenolic compounds, carotenoids and ascorbic acid content. J. Food Eng. 2017, 213, 27-37. [CrossRef]

88. Goodman, C.; Fawcett, S.; Barringer, S. Flavor, Viscosity, and Color Analyses of Hot and Cold Break Tomato Juices. J. Food Sci. 2002, 67, 404-408. [CrossRef]

89. Ayer, N.W.; Tyedmers, P.H. Assessing alternative aquaculture technologies: Life cycle assessment of salmonid culture systems in Canada. J. Clean. Prod. 2009, 17, 362-373. [CrossRef]

90. Løland, A.; Aldrin, M.; Steinbakk, G.H.; Huseby, R.B.; Grøttum, J.A.; Quinn, T.J. Prediction of biomass in Norwegian fish farms. Can. J. Fish. Aquat. Sci. 2011, 68, 1420-1434. [CrossRef]

91. El-Sayed, A.F.M.; Kawanna, M. Optimum water temperature boosts the growth performance of Nile tilapia (Oreochromis niloticus) fry reared in a recycling system. Aquac. Res. 2008, 39, 670-672. [CrossRef]

92. Badiola, M.; Basurko, O.; Gabiña, G.; Mendiola, D. Integration of energy audits in the Life Cycle Assessment methodology to improve the environmental performance assessment of Recirculating Aquaculture Systems. J. Clean. Prod. 2017, 157, 155-166. [CrossRef]

93. Espinal, C.A.; Matulić, D. Recirculating Aquaculture Technologies. In Aquaponics Food Production Systems: Combined Aquaculture and Hydroponic Production Technologies for the Future; Goddek, S., Joyce, A., Kotzen, B., Burnell, G.M., Eds.; Springer International Publishing: Cham, Switzerland, 2019; pp. 35-76. [CrossRef]

94. Badiola, M.; Basurko, O.; Piedrahita, R.; Hundley, P.; Mendiola, D. Energy use in Recirculating Aquaculture Systems (RAS): A review. Aquac. Eng. 2018, 81, 57-70. [CrossRef]

95. Liu, Y.; Rosten, T.W.; Henriksen, K.; Hognes, E.S.; Summerfelt, S.; Vinci, B. Comparative economic performance and carbon footprint of two farming models for producing Atlantic salmon (Salmo salar): Land-based closed containment system in freshwater and open net pen in seawater. Aquac. Eng. 2016, 71, 1-12. [CrossRef]

96. D'Orbcastel, E.R.; Blancheton, J.P.; Aubin, J. Towards environmentally sustainable aquaculture: Comparison between two trout farming systems using Life Cycle Assessment. Aquac. Eng. 2009, 40, 113-119. [CrossRef]

97. Stévant, P.; Rebours, C.; Chapman, A. Seaweed aquaculture in Norway: Recent industrial developments and future perspectives. Aquac. Int. 2017, 25, 1373-1390. [CrossRef]

98. Titlyanov, E.A.; Titlyanova, T.V. Seaweed cultivation: Methods and problems. Russ. J. Mar. Biol. 2010, 36, 227-242. [CrossRef]

99. Andersen, M. Opportunities and Risks of Seaweed Biofuels in Aviation; Technical Report; The Bellona Foundation: Oslo, Norway, 2017.

100. Djaeni, M.; Sari, D.A. Low Temperature Seaweed Drying Using Dehumidified Air. Procedia Environ. Sci. 2015, 23, 2-10. [CrossRef]

101. Stévant, P.; Indergård, E.; Ólafsdóttir, A.; Marfaing, H.; Larssen, W.E.; Fleurence, J.; Roleda, M.Y.; Rustad, T.; Slizyte, R.; Nordtvedt, T.S. Effects of drying on the nutrient content and physico-chemical and sensory characteristics of the edible kelp Saccharina latissima. J. Appl. Phycol. 2018, 30, 2587-2599. [CrossRef]

102. Silva, A.; Abreu, H.; Silva, A.; Cardoso, S. Effect of Oven-Drying on the Recovery of Valuable Compounds from Ulva rigida, Gracilaria sp. and Fucus vesiculosus. Mar. Drugs 2019, 17, 90. [CrossRef]

103. Jensen, A. Present and future needs for algae and algal products. In Proceedings of the Fourteenth International Seaweed Symposium, Brest, France, 16-21 August 1992; Developments in Hydrobiology; Springer: Berlin/Heidelberg, Germany, 1992. 
104. Van Oirschot, R.; Thomas, J.B.E.; Gröndahl, F.; Fortuin, K.P.; Brandenburg, W.; Potting, J. Explorative environmental life cycle assessment for system design of seaweed cultivation and drying. Algal Res. 2017, 27, 43-54. [CrossRef]

105. Philis, G.; Gracey, E.O.; Gansel, L.C.; Fet, A.M.; Rebours, C. Comparing the primary energy and phosphorus consumption of soybean and seaweed-based aquafeed proteins-A material and substance flow analysis. J. Clean. Prod. 2018, 200, 1142-1153. [CrossRef]

106. Strømmen, I.; Eikevik, T.M.; Alves-Filho, O.; Syverud, K.; Jonassen, O. Low temperature drying with heat pumps new generations of high quality dried products. In Proceedings of the 2nd Nordic Drying Conference, Aarhus, Denmark, 19-23 October 2002.

107. Mujumdar, A. Handbook of Industrial Drying, 4th ed.; CRC Press: Boca Raton, FL, USA , 2014.

108. Kumar, C.; Karim, M.A. Microwave-convective drying of food materials: A critical review. Crit. Rev. Food Sci. Nutr. 2019, 59, 379-394. [CrossRef]

109. Hart, O. Pulse Combustion Drying with Superheated Steam. In Proceedings of the Nordic Baltic Drying Conference, Hamburg, Germany, 7-9 June 2017.

110. Joint FAO/WHO Food Standards Programme. Comments of Lao PDR: Development of Regional Standard for Edible Crickets and Their Products; Technical Report; Joint FAO/WHO Food Standards Programme: Rome, Italy, 2010.

111. Fowles, T.M.; Nansen, C. Insect-Based Bioconversion: Value from Food Waste. In Food Waste Management: Solving the Wicked Problem; Närvänen, E., Mesiranta, N., Mattila, M., Heikkinen, A., Eds.; Springer International Publishing: Cham, Switzerland, 2020; pp. 321-346. [CrossRef]

112. Wang, H.; Hagemann, A.; Reitan, K.; Ejlertsson, J.; Wollan, H.; Handå, A.; Malzahn, A. Potential of the polychaete Hediste diversicolor fed on aquaculture and biogas side streams as an aquaculture food source. Aquac. Environ. Interact. 2019, 11, 551-562. [CrossRef]

113. Van Huis, A.; Oonincx, D. The environmental sustainability of insects as food and feed. A review. Agron. Sustain. Dev. 2017, 35, 1-14. [CrossRef]

114. Tran, G.; Gnaedinger, C.; Melin, C. Mealworm (Tenebrio Molitor); Technical Report; Feedipedia, a Programme by INRA, CIRAD, AFZ and FAO; FAO: Rome, Italy, 2019

115. Dortmans, B.; Diener, S.; Verstappen, B.; Zurbrugg, C. Black Soldier Fly Biowaste Processing—A Step-by-Step Guide; Technical Report; Eawag: Swiss Federal Institute of Aquatic Science and Technology: Dibendorf, Switzerland, 2017.

116. Ingraham, C. Maggots: A taste of food's future. The Washington Post. 2019. Available online: https:/ / www.washingtonpost.com /business/2019/07/03/maggots-could-revolutionize-global-food-supply-heres-how / (accessed on 20 November 2020) .

117. Scaps, P. A review of the biology, ecology and potential use of the common ragworm Hediste diversicolor (O.F. Müller) (Annelida: Polychaeta). Hydrobiologia 2002, 470, 203-218. [CrossRef]

118. Ramos-Elorduy, J.; González, E.A.; Hernández, A.R.; Pino, J.M. Use of Tenebrio molitor (Coleoptera: Tenebrionidae) to Recycle Organic Wastes and as Feed for Broiler Chickens. J. Econ. Entomol. 2002, 95, 214-220. [CrossRef]

119. Park, J.B.; Choi, W.H.; Kim, S.H.; Jin, H.J.; Han, Y.S.; Lee, Y.s.; Kim, N.J. Developmental characteristics of Tenebrio molitor larvae (Coleoptera: Tenebrionidae) in different instars. Int. J. Ind. Entomol. 2014, 28, 5-9 . [CrossRef]

120. Kawasaki, K.; Hashimoto, Y.; Hori, A.; Kawasaki, T.; Hirayasu, H.; Iwase, S.; Hashizume, A.; Ido, A.; Miura, C.; Miura, T.; et al. Evaluation of Black Soldier Fly (Hermetia illucens) Larvae and Pre-Pupae Raised on Household Organic Waste, as Potential Ingredients for Poultry Feed. Animals 2019, 9, 98 . [CrossRef]

121. Chia, S.Y.; Tanga, C.M.; Khamis, F.M.; Mohamed, S.A.; Salifu, D.; Sevgan, S.; Fiaboe, K.K.M.; Niassy, S.; van Loon, J.J.A.; Dicke, M.; et al. Threshold temperatures and thermal requirements of black soldier fly Hermetia illucens: Implications for mass production. PLoS ONE 2018, 13, 1-26. [CrossRef]

122. Ozoh, P.; Jones, N. Capacity adaptation of Hediste (Nereis) diversicolor embryogenesis to salinity, temperature and copper. Mar. Environ. Res. 1990, 29, 227-243. [CrossRef]

123. Cadinu, L.A.; Barra, P.; Torre, F.; Delogu, F.; Madau, F.A. Insect Rearing: Potential, Challenges, and Circularity. Sustainability 2020, 12, 4567. [CrossRef]

124. Dias, G.M.; Ayer, N.W.; Khosla, S.; Van Acker, R.; Young, S.B.; Whitney, S.; Hendricks, P. Life cycle perspectives on the sustainability of Ontario greenhouse tomato production: Benchmarking and improvement opportunities. J. Clean. Prod. 2017, 140, 831-839. [CrossRef]

125. Schieber, A.; Stintzing, F.; Carle, R. By-products of plant food processing as a source of functional compounds-Recent developments. Trends Food Sci. Technol. 2001, 12, 401-413. [CrossRef]

126. Van Dyk, J.; Gama, R.; Morrison, D.; Swart, S.; Pletschke, B. Food processing waste: Problems, current management and prospects for utilisation of the lignocellulose component through enzyme synergistic degradation. Renew. Sustain. Energy Rev. 2013, 26, 521-531. [CrossRef]

127. Avelino, A. Saccharification of tomato pomace for the production of biomass. Bioresour. Technol. 1997, 61, 159-162. [CrossRef]

128. Makkar, H.P.S.; Tran, G.; Heuzé, V.; Ankers, P. State-of-the-art on use of insects as animal feed. Anim. Feed. Sci. Technol. 2014, 197, 1-33. [CrossRef]

129. Invertapro, Insects for a Circular Economy. 2020. Available online: https://www.invertapro.com/products (accessed on 28 March 2021). 
130. Gold, M.; Cassar, C.M.; Zurbrügg, C.; Kreuzer, M.; Boulos, S.; Diener, S.; Mathys, A. Biowaste treatment with black soldier fly larvae: Increasing performance through the formulation of biowastes based on protein and carbohydrates. Waste Manag. 2020, 102, 319-329. [CrossRef]

131. Gold, M.; Tomberlin, J.K.; Diener, S.; Zurbrügg, C.; Mathys, A. Decomposition of biowaste macronutrients, microbes, and chemicals in black soldier fly larval treatment: A review. Waste Manag. 2018, 82, 302-318. [CrossRef]

132. Del Campo, L.M.; Ibarra, P.; Gutierrez, X.; Takle, H.R. Utilization of Sludge from Recirculation Aquaculture Systems; Technical Report; Nofima AS: Ås, Norway, 2010.

133. Gahukar, R. Edible Insects Farming: Efficiency and Impact on Family Livelihood, Food Security, and Environment Compared With Livestock and Crops. In Insects as Sustainable Food Ingredients; Elsevier: Berlin/Heidelberg, Germany, 2016; pp. 85-111. [CrossRef]

134. Madau, F.A.; Arru, B.; Furesi, R.; Pulina, P. Insect Farming for Feed and Food Production from a Circular Business Model Perspective. Sustainability 2020, 12, 5418. [CrossRef]

135. Dobermann, D.; Swift, J.A.; Field, L.M. Opportunities and hurdles of edible insects for food and feed. Nutr. Bull. 2017, 42, 293-308. [CrossRef]

136. IPIFF. Regulation (EU) 2015/2283 on Novel Foods-Briefing Paper on the Provisions Relevant to the Commercialization of Insect-Based Products Intended for Human Consumption in the EU; IPIFF: Brussels, Belgium, 2019.

137. Mattilsynet (Norwegian Food Safety Authority). Insekter til Bruk i fôr, 2020. Available online: https://www.mattilsynet.no/ma t_og_vann/produksjon_av_mat/ny_mat/insekter_som_mat.22375 (accessed on 25 November 2020).

138. Skretting. Sustainability Report. Skretting Sustainability Performance; Skretting: Stavanger, Norway, 2019.

139. Winther, U.; Hognes, E.S.; Jafarzadeh, S.; Ziegler, F. Greenhouse Gas Emissions of Norwegian Seafood Products in 2017. Available online: https:/ / www.sintef.no/contentassets /25338e561f1a4270a59ce25bcbc926a2/report-carbon-footprint-norwegian-seafo od-products-2017\{_\}final\{_\}040620.pdf/ (accessed on 29 November 2020).

140. MacLeod, M.J.; Hasan, M.R.; Robb, D.H.F.; Mamun-Ur-Rashid, M. Quantifying greenhouse gas emissions from global aquaculture. Sci. Rep. 2020, 10, 11679. [CrossRef]

141. Belghit, I.; Liland, N.S.; Waagbø, R.; Biancarosa, I.; Pelusio, N.; Li, Y.; Krogdahl, Å.; Lock, E.J. Potential of insect-based diets for Atlantic salmon (Salmo salar). Aquaculture 2018, 491, 72-81. [CrossRef]

142. Belghit, I.; Liland, N.S.; Gjesdal, P.; Biancarosa, I.; Menchetti, E.; Li, Y.; Waagbø, R.; Krogdahl, Å.; Lock, E.J. Black soldier fly larvae meal can replace fish meal in diets of sea-water phase Atlantic salmon (Salmo salar). Aquaculture 2019, 503, 609-619. [CrossRef]

143. Liland, N.S.; Biancarosa, I.; Araujo, P.; Biemans, D.; Bruckner, C.G.; Waagbø, R.; Torstensen, B.E.; Lock, E.J. Modulation of nutrient composition of black soldier fly (Hermetia illucens) larvae by feeding seaweed-enriched media. PLoS ONE 2017, 12, e0183188. [CrossRef] [PubMed]

144. Chopin, T.; Robinson, S.; Troell, M.; Neori, A.; Buschmann, A.; Fang, J. Multitrophic Integration for Sustainable Marine Aquaculture. In Encyclopedia of Ecology; Elsevier: Amsterdam, The Netherlands, 2008; pp. 2463-2475. [CrossRef]

145. Lennard, W.; Goddek, S. Aquaponics: The Basics. In Aquaponics Food Production Systems: Combined Aquaculture and Hydroponic Production Technologies for the Future; Goddek, S., Joyce, A., Kotzen, B., Burnell, G.M., Eds.; Springer International Publishing: Cham, Switzerland , 2019; pp. 113-143. [CrossRef]

146. Lipper, L.; Thornton, P.; Campbell, B.M.; Baedeker, T.; Braimoh, A.; Bwalya, M.; Caron, P.; Cattaneo, A.; Garrity, D.; Henry, K.; et al. Climate-smart agriculture for food security. Nat. Clim. Chang. 2014, 4, 1068-1072. [CrossRef]

147. Palm, H.W.; Knaus, U.; Appelbaum, S.; Goddek, S.; Strauch, S.M.; Vermeulen, T.; Haïssam Jijakli, M.; Kotzen, B. Towards commercial aquaponics: A review of systems, designs, scales and nomenclature. Aquac. Int. 2018, 26, 813-842. [CrossRef]

148. Goddek, S.; Joyce, A.; Wuertz, S.; Körner, O.; Bläser, I.; Reuter, M.; Keesman, K.J. Decoupled Aquaponics Systems. In Aquaponics Food Production Systems: Combined Aquaculture and Hydroponic Production Technologies for the Future; Goddek, S., Joyce, A., Kotzen, B., Burnell, G.M., Eds.; Springer International Publishing: Cham, Switzerland, 2019; pp. 201-229. [CrossRef]

149. Delaide, B.; Monsees, H.; Gross, A.; Goddek, S. Aerobic and Anaerobic Treatments for Aquaponic Sludge Reduction and Mineralisation. In Aquaponics Food Production Systems: Combined Aquaculture and Hydroponic Production Technologies for the Future; Goddek, S., Joyce, A., Kotzen, B., Burnell, G.M., Eds.; Springer International Publishing: Cham, Switzerland, 2019; pp. 247-266. [CrossRef]

150. Goddek, S.; Körner, O. A fully integrated simulation model of multi-loop aquaponics: A case study for system sizing in different environments. Agric. Syst. 2019, 171, 143-154. [CrossRef]

151. Palm, H.; Strauch, S.; Knaus, U.; Wasenitz, B. Das FischGlasHaus-eine Innovationsinitiative zur energie- und nährstoffeffizienten Produktion unterschiedlicher Fisch- und Pflanzenarten in Mecklenburg-Vorpommern ("Aquaponik in MV"). Fisch. Fisch. M-V 2016, 1, 38-47.

152. Skar, S.L.G.; Liltved, H.; Kledal, P.R.; Høgberget, R.; Björnsdottir, R.; Homme, J.M.; Oddsson, S.; Paulsen, H.; Drengstig, A.; Savidov, N.; et al. Aquaponics NOMA (Nordic Marine)-New Innovations for Sustainable Aquaculture in the Nordic Countries; Technical Report; Nordic Innovation: Oslo, Norway , 2015.

153. Beckers, S. Aquaponics: A positive impact circular economy approach TO feeding cities. J. Field Actions 2019, $20,78-84$.

154. Seghetta, M.; Hou, X.; Bastianoni, S.; Bjerre, A.B.; Thomsen, M. Life cycle assessment of macroalgal biorefinery for the production of ethanol, proteins and fertilizers-A step towards a regenerative bioeconomy. J. Clean. Prod. 2016, 137, 1158-1169. [CrossRef] 
155. Turnšek, M.; Morgenstern, R.; Schröter, I.; Mergenthaler, M.; Hüttel, S.; Leyer, M. Commercial Aquaponics: A Long Road Ahead. In Aquaponics Food Production Systems: Combined Aquaculture and Hydroponic Production Technologies for the Future; Goddek, S., Joyce, A., Kotzen, B., Burnell, G.M., Eds.; Springer International Publishing: Cham, Switzerland, 2019; pp. 453-485. [CrossRef]

156. Nikolaisen, M.; Andresen, T. System impact of heat exchanger pressure loss in ORCs for smelter off-gas waste heat recovery. Energy 2021, 215, 118956. [CrossRef]

157. Royo, P.; Acevedo, L.; Ferreira, V.J.; García-Armingol, T.; López-Sabirón, A.M.; Ferreira, G. High-temperature PCM-based thermal energy storage for industrial furnaces installed in energy-intensive industries. Energy 2019, 173, 1030-1040. [CrossRef]

158. Beck, A.; Sevault, A.; Drexler-Schmid, G.; Schöny, M.; Kauko, H. Optimal Selection of Thermal Energy Storage Technology for Fossil-Free Steam Production in the Processing Industry. Appl. Sci. 2021, 11, 1063. [CrossRef] 